Article

\title{
A Perfect Chord: Trinity in Music, Music in the Trinity
}

\section{Chiara Bertoglio}

Facoltà Teologica dell'Emilia Romagna, Bologna, Corso Monte Cucco, Turin 125, I-10141, Italy; E-Mail: chiara@chiarabertoglio.com; Tel.:+39-335-526-11-46

Received: 9 September 2013; in revised form: 24 September 2013 / Accepted: 1 October 2013 / Published: 9 October 2013

\begin{abstract}
The doctrine of God's Triunity is at the core of Christian faith; this article presents a theological survey of how it has been understood in a musical way during the Christian era. The role of music as a participation in the liturgy of mutual love eternally experienced in the Trinity is first analyzed, with references to the Church Fathers and to modern/contemporary theologians. Later, the three main forms of congregational singing are taken into account (i.e., monody, polyphony and harmony), pointing out how each has been seen in turn as a symbol of the Trinity's love.
\end{abstract}

Keywords: Trinity; liturgy; monody; polyphony; harmony; history of music

\section{Introduction}

The French composer Olivier Messiaen (1908-1992), who was an ornithologist as well as a theologian, used to say that his music aimed at transmitting theological truths (quoted in [1], p. 21). Thus, he linked together the contemplative aspect that can be art's best and greatest result with an aspect of reflection and higher comprehension (rational and aware) of the Christian mystery. In this article, we will be moving from this concept to ask some questions: Can music help us to "say" and to "understand" something of the ineffable and unattainable mystery of the Trinity? If yes, how? During the two thousand years of Christianity in music, how were the Trinitarian subjects treated by musicians?

In many cases, it will be necessary to refer to concepts which are typical of the theory of music, of music analysis and musicology. Indeed, throughout the History of Music, it was usual for composers to entrust their message to different interpretive levels: from the simple "emotional" level to the evocation of a "feeling", from the use of symbologies and onomatopoeias which everybody could understand, to the application of compositional strategies of a noteworthy complexity and refinement. It is self-evident, therefore, that a subject which is both as fundamental and demanding as that of the 
Trinity has required all of their artistic resources, often encouraging a very refined compositional style whose full appreciation is only possible to specialists. At the same time, many composers of the past had a belief, which is less and less frequently found nowadays, i.e., that the value of their work was primarily in its generative intention and in its intrinsic correspondence with the mystery it aimed at expressing.

As a consequence, the fact that not all hearers could have understood the "how" and the "why" of certain compositional decisions (whose very existence would have passed unnoticed by many) was a result not only foreseen, but often wanted by the composers themselves. Within the framework of a Christian belief, a work can act as an instrument of Grace even if the hearer is not aware of how it operates. Therefore, Christian composers could (and can) believe that a salvific message encoded within the score can reach the hearers' soul even if they do not realize how and why it is encrypted. Bach's works are a paradigmatic example of this approach: although we cannot expound this subject sufficiently here, it should be mentioned that Bach realized an exceptional theological and mystical exegesis of the Trinitarian dogmas in many of his works, such as the Klavierübung III or the B-minor Mass - to name but two - as well as in several works which were not explicitly "sacred" (cf. also [2], pp. 142ff.).

\section{The Liturgy of Trinitarian Love}

In order to consider the connection of music with the Trinity, we must focus first on the role of liturgical music within the Trinity and between the Triune God and the Church (as well as humankind). Besides liturgical music, we should not omit consideration of sacred music, and eventually the non-sacred music in its most beautiful, highest and truest significance.

This subject was frequently treated by the Church Fathers, and has been later resumed, in recent years, by some great theologians. In the meantime, this subject was treated more often in practice by music and liturgy, and less frequently in theory and speculation.

For Clemens of Alexandria, man is the "musical instrument" of the Logos, who made him "harmonious" through the Holy Spirit: so that the divine harmony may resound in him, that he may receive and worship the Word, and that the Spirit may "blow" him, similar to a pipe, giving him life and making him an instrument of praise ([3], p. 326; [4], p. 91; cf. [5], p. 25). Being the divine image of the Logos, moreover, man participates in the Trinitarian communion when he becomes an instrument of the Logos' praise to the Father ([3], p. 326; [4], p. 643. The Trinitarian interpretation is supported by [6], p. 118, and [7], p. 114); for Clemens, the divine Word is "the only instrument of peace, the only Logos through whom we honor God" (in [8], vol. VIII, p. 443).

Augustine's viewpoint was different but complementing: "In that supreme triad is the source of all things, and the most perfect beauty, and wholly blissful delight” ([9], p. 215; cf. [10], pp. 124, 134). It is not surprising that a reflection on beauty and the Trinity was particularly interesting for the Bishop of Hippo, whose writings "testify upon a double concern: for beauty and for Trinitarian theology" ([10], p. 124). Being a form of creation, albeit a human one, for Augustine musical composition is somehow a participation in the Father's creative activity: "The Father is the origin of all being, and therefore the 
origin of all beautiful-being as well”, as Tscholl summarizes it ([10], p. 125) ${ }^{1}$. When music becomes liturgy, worship, prayer or contemplation, it becomes an act of thanksgiving, realized through the Son in the Spirit, as John Chrysostom seems to suggest in pages of exquisite beauty, where dance is a further element of praise within Trinitarian communion (Hom. I,1, In illud. Vidi Dominum: [8], vol. LVI, p. 98).

Chrysostom expounds further on the Trinitarian concept of human music as praise for God: "Music is a heavenly invention; if man is a musician, he is so for a revelation of the Holy Spirit." ([8], vol. LVI, p. 98). These are challenging words: "a revelation of the Holy Spirit" is a definition normally reserved for things other than music.

In recent times, these subjects have been interestingly treated by Christian theologians. Ratzinger underlines the Trinitarian value of liturgical music. Since it has a verbal text, it is rooted within the Easter Mystery, and in the divine revelation given to us by Scripture: "There is a clear sovereignty of the word, which is a higher mode of preaching. [...] To refer to the Logos means, therefore, to refer primarily to the word" ([13], pp. 44-45). In consequence, it participates both in the mystery of Christ's kenosis and in the Easter joy; moreover, it is a gift of the Spirit of Love in his action, in communion with the Logos ([13], p. 45).

Hart analyses what Bach's music reveals about his creative activity and process to make it a symbol of the divine creativity in a Trinitarian sense. Bach's music demonstrates the possibility of a diversity intrinsic to unity ([14], pp. 282-85), of a creation which implies acceptance (cf. [15], chapter 5), of the virtual boundlessness of thematic development ([16], p. 469) and of the simultaneous presence of radical openness with an equally radical consistency: although no first-time hearer can anticipate how a work by Bach will progress and develop, nonetheless it strikes us for the impression of cogency and consequentiality we feel (cf. [14], p. 277). According to Hart, awareness of these realities can lead us to a deeper "Trinitarian" understanding of Creation: its variety and diversity are the "logical" consequence of the inherence of diversity to divine Triunity. The Creation is not reducible to an abstract plan, but is rather a gift of love; finally, the seeming unlimitedness of Creation's possible development is a testimony of the infinity of the Trinitarian love.

Commenting upon Hart's statements, Begbie observes that they mirror a vision of the creature/Creator relationship as "a cosmos that reflects and shares in the life and love of a Triune God." ([17], p. 137). Furthermore, as Horne points out, it is precisely within a Trinitarian concept of creation that human creativity is not in competition with that of God, but rather a participation in communion with it ([18], p. 8ff). Through the Incarnation, the eternal dialogue of Father and Son is transferred into the world of created matter; artistic creation, being a creative response to the creating love, becomes necessary, even unavoidable, in the Spirit.

Also for Jenson, Trinitarian communion is "a song", within which man is "driven", and in which, by Grace, he is called to participate. It is not for a simple love for decoration that the Church promotes beauty in preaching and liturgy: "A congregation singing a hymn of praise to the Father is doubling the

1 Also the 15th-century philosopher John Ireland used the musical metaphor to symbolise God's creative activity and his relationship with creation; they were comparable, in his opinion, to those between a composer and his musical work (cf. [11], p. 66; cf. however [12], p. 233). 
Son's praise, and the surge of rhythm and melody is the surge of the Spirit's glorification of the Father and the Son" ([19], p. 235) 2 .

Indeed, liturgy is primarily to receive God in one's personal and communitarian life (cf. Rev. 3:20). In consequence, the dimension of relationship with God (and through this, with the ecclesial and human community), becomes almost a cantus firmus unifying the different modes of realization of liturgy itself. Regardless of the difference in Christian confessions, musical styles, historic periods or geographical collocations, it is always the Spirit who is the true cantus firmus of liturgical action, as he directly and constantly arouses the Church's praise ([4], p. 109).

Liturgy is therefore rooted in, built upon, and caused by God's love, the reciprocal love of Father and Son. The presence of this cantus, thus, is not only an element of union among the different forms of liturgy and prayer, but also a vehicle through which liturgy itself is inserted within the Trinity's dynamic of reciprocal love and praise.

\section{The Harmony of Creation, the Harmony of the Creator}

In Greek theory and philosophy, since music is an expression of order and harmony, it is analogous with the harmony of nature, and is sympathetic with it. For Christians, the harmony of creation mirrors the Creator (cf. Wisdom 19:18), whose Triune nature is the perfect expression of harmony and the model of all created harmony. In the wake of Pythagorean physics and philosophy, in the ancient world an interval's degree of consonance was in proportion to the simplicity of their frequency ratio (thus the octave, $2: 1$, and the fifth, $3: 2$, were extremely consonant, whereas the third and the sixth were not).

From the one side, Augustine points out that rhythm and measure (which are the fruits of the Logos' divine wisdom) are fundamental for music ([10], p. 53; [21], p. 45). From the other, concordance and harmony, both in music and in creation, are icons of the perfect concord realized in Trinitarian life ([22], p. 235; [23], p. 9). Summarizing the history of liturgical music, Ratzinger underlines the deep communion between Logos and Spirit: "The mathematics of the universe [...] has a deeper foundation: the mind of the Creator. It comes from the Logos, in whom, so to speak, the archetypes of the world's order are contained. The Logos, through the Spirit, fashions the material world according to these archetypes. [...] The Logos Himself is the great artist, in whom all works of art [and] the beauty of the universe have their origin" [24]. This concept has something in common with Balthasar's, for whom music allows us to draw on the logic of creation, or, better, to the Logos through Whom the universe exists ([25], p. 47).

Returning to the time when these concepts were defined, in the Middle Ages a special mention is reserved for John Scotus Eriugena, who proposed an analogy between the harmony of the cosmos and musical harmony, with a reference to what has been often interpreted as polyphony (in [26], vol. 122, pp. 637-38; cf. [27]). It can be said that the idea according to which musical harmony (in the broadest sense) mirrors the harmony of the cosmos is a consequence of what we are discussing here: i.e., that

2 This concept is also present in Hildegard von Bingen. She expounds on the subject, particularly as it concerns the human participation in the Trinity's liturgy of love. For her, music is a primary gift of God, essentially connected with the life-giving Spirit. Through sin, mankind loses the possibility of "tuning itself" with the cosmic praise of the "spirits" (cf. [20], lines 99-101, 68-69, 71-75, 84-94). 
the Trinitarian harmony/polyphony is the model of all musical harmony/polyphony; and that music, in turn, may symbolize it much less inadequately than other languages.

Monodic Christian singing thus becomes a powerful experiential icon and a vehicle of communion with Trinitarian life; it unifies and creates, both in image and in act, a concord, which is apparent in sounds but is generated in souls. This is the viewpoint of Hildegard von Bingen, for whom the creation's accomplishment is the resonance of the harmony of human praise in God. Creation thus finds its authentic and deep meaning when there is harmony between humankind and cosmos, whereas man finds his sense (i.e., that of a creature similar to God) through the harmony between his own praise and that of the angels. Music touches the listener, awakening his nostalgia for the heavenly fatherland. Listening to a "symphony" (a "concord" music) generates a resonance in men, since "anima hominis symphonia in se habet et symphonizans est" ([28], p. 13, 202 etc.) and "symphonalis est anima" ([20], line 141; cf. [29]).

For Hildegard, the re-establishment of the "symphony" is a gift of Grace as well as the result of human efforts: the musical "sym-phony" is, at the same time, an image as well as an operating reality of the soul's concord. In the life of her monastic community, she states, this "symphony" of the voices is a "process": voices "tuning" with each other and with the angels praise, hears "tuning" with each other in the reciprocal communion, and in communion with creation and with God (cf. [29], pp. 4-5; cf. [20], lines 126-28). This concept was also held by the $13^{\text {th }}$-century poet Pierre de Peckham: for him there was an analogy between the "concord" vibration of three harp strings and the Trinity (cf. [30], p. 53).

\section{God: The Lord of Time}

In the $14^{\text {th }}$ century, the extraordinary development of written polyphonic sacred music begins, producing works of immense contrapuntal complexity, composed at first in the Flanders and Burgundy, and later throughout Europe ${ }^{3}$. Here, the connections between music theory and theology emerge both at the level of polyphony in se and that concerning its technical requirements: in order to coordinate the evolution of melodic lines whose degree of complexity and reciprocal liberty was ever increasing, it became necessary to notate, codify and organize the musical tempo, through the introduction of the notions of color and talea.

3 A few very short terminological and aesthetical clarifications. By "polyphony" we mean the simultaneous production of two or more melodic lines, the "voices", with their own independent consistency, which combine with one another according to contrapuntal laws. "Imitation" is the quotation of a voice's motif or musical phrase by another, with a temporal gap. When the quotation is literal, with all intervals identical to the original and by complete sections, we have a "canon". Many polyphonic works are on cantus firmus. This is a melody, often taken from the Gregorian repertoire, which is performed, in long notes, by one of the voice, and to which all the others relate. It is, so to say, the foundation of the contrapuntal building. The polyphony's "dimension" is prevailingly "horizontal", in reference to the graphic/notational conventions, precisely since the aesthetic evaluation of a contrapuntal work takes into account, in primis, both the lines' beauty and their interplay on the "long distance"; on the other hand, harmony is rather "vertical" and proceeds by instants. Polyphonic processes allow the coexistence of intervals which can sometimes be very dissonant, but which are not felt as disagreeable since the relative independence of the parts is perceived as a "guarantee" of their eventual ending on consonant intervals: it is a symbolic game of anticipation, similar to the narrative schemes of comedy or whodunit criminal novels. 
The rhythmic theory of the late Middle Ages had been elaborated by the School of Notre Dame through the creation of rhythmical "modes", inspired by the melodic modes, which were based on different subdivisions of one (or two) ternary tempo units (cf. [31], p. 56. As concerns mode III, however, cf. [32], pp. 319-20). Notwithstanding this, according to Walter de Odington, a monk from Evesham by Worcester, the first organa (sacred two-part works) frequently adopted binary rhythms; however, he believed that the later establishment of a system of ternary subdivisions was indebted to the idea of three being the perfect number, in homage to the Trinity (quoted in [33], vol. 1, p. 235; cf. [34], p. 96). Historical research has shown that, contrary to Odington's belief, the first organa were unmeasured, and that their rhythmical organization was determined by the prosodic and metrical structure of the sung text). Reference to the Trinity in ternary rhythmic subdivisions is particularly clear in Johannes de Anagnia's treatise on the mensuration system ([35], especially pp. 16-24 and 39). It was Philippe de Vitry who later codified and generalized a rhythmic system which favored the "perfect" ternary subdivisions to that of the binary: perfect or imperfect modes, depending on the kind of longa; perfect or imperfect tempi, following the division of the brevis; "major" (perfect) and "minor" prolationes depending on the semibrevis' subdivision.

As summarised by Reese, within the process of the theoretical codification of musical rhythm, the nature of rhythm nature began to be understood as ternary, closely linked to the concept of perfection ([36], pp. 302-03). The thirteenth-century theorist Franco of Cologne (doc. 1250-1280), whose Ars Cantus Mensurabilis (cf. [33], vol. 1, pp. 117ff.) enjoyed an immense success during the Middle Ages and Renaissance, established that the longa perfecta was the principal tempo unit; this view contrasted with that of Johannes de Garlandia, for whom the longa perfecta was a composite unit, made of a longa imperfecta and a brevis. Since then, as Busse Berger maintains, "the ternary division of the perfect long, which he associated with the Holy Trinity, was to become the basic mensuration unit in French music theory" ([37], p. 632). The ternary subdivision thus becomes a "theologized" tempo (Rainoldi), in consequence of the reference to the Trinity ([4], p. 268). Similarly, Blankenburg states that the proportions of color and talea in the isorhythmic motets of the Ars Nova were conceived as the microcosmic image of the macrocosmic order established by God ([38], col. 1973; cf. Johannes de Muris, in [39], pp. 67 and 71).

The ternary nature of music is thus molded upon the Trinitarian model: although a similar concept was not always expressed in similar words, as Leaver points out ([40], p. 98), the common interpretation of the Patristic texts on this subject was in conformity with the synthesis made by Johannes de Muris.

\section{A "Polyphonic" God}

The musical concept of polyphony is adopted by Cunningham ([41], especially pp. 127ff.) as a paradigm of and an overall frame for all attempts to approximate and partially comprehend the Trinitarian mystery. Moreover, it also proves itself fruitful with regard to different (although related and derived) relationships, as that between God and man, or those among human beings within a community, and particularly within the Church. In polyphonic music, for Cunningham, being one and being three is not a violation of the principle of non-contradiction: relationality (between sounds or between people) is the natural dimension of music. Moreover, polyphony's "chief attribute is 
simultaneous, non-excluding difference: that is, more than one note is played at a time, and none of these notes is so dominant that it renders another mute" ([41], p. 128).

Dietrich Bonhoeffer significantly used the musical image of the counterpoint between cantus firmus and higher parts as a metaphor of our love for creation and Creator: our love for God is the basic melody, "to which the other melodies of life provide the counterpoint" ([42], p. 192). As Cunningham points out, this is not a casual juxtaposition of sounds, but a "relationship among various melodies" ([41], p. 130). For Balthasar, creation is like a symphony, composed and conducted by God, where plurality is a gift (and not a defect), provided that there is the availability to "tune oneself symphonically with the other" for the purpose of a transcendent unity ([43], pp. 7-8). This metaphor is carried further by Balthasar to introduce a genuinely Trinitarian argument: it is impossible to "comprehend", in the word's deepest sense, the mystery of Christ if we try to "grasp" it, to reduce it to a merely earthily dimension ([43], pp. 11-12) ${ }^{4}$.

The contrapuntal technique of the canon has a deeply theological value as well, and it was often deliberately used by composers in this sense. Since the canon's comes, i.e., the second part, is rigorously derived from the $d u x$, it is properly "generated" by the former, and not "created" by the composer: therefore, this process is particularly suitable for musical depictions of the Son, especially within the liturgical Credo ${ }^{5}$. Using a retrograde or inverse comes, moreover, is a poignant symbol for the Son, who is an image, a "mirror" of the Father".

Polyphony thus becomes a significant icon of the Trinity, as a few examples (taken from among the innumerable one could mention) will show. The first two are taken from two versions of the Duo

4 Milbank, quoting often from Augustine's De Musica, uses the idea of polyphony, applying it to the believing community, whose objective is "a consensus that is only in and through the inter-relations of the community itself, and a consensus that moves and 'changes': a concentus musicus" ([44], p. 227).

5 In my opinion, a number of passages from the sacred repertoire could be interpreted within this framework: cf. the "genitum, non factum" in the Missa Ecce Ancilla Domini/Beata es Maria by Guillaume Dufay; the same passage in the Missa Hercules Dux Ferrariae by Josquin Desprez; the "Filium Dei unigenitum" in the Missa Sine Nomine n. 2 by Johannes Tinctoris; etc. Bach's solution is particularly interesting: in the Credo of his B-minor Mass, the text "genitum, non factum, [...] per quem omnia facta sunt" is set by Bach as an imitation, a "quasi-canon". The choice is particularly significant: the idea of canon brings to mind the concept of "generation" of the comes by the dux (and not of "creation" by the composer), whereas the liberties taken by Bach represent the distinction of the Son's person from that of the Father (cf. [45] and [46], especially pp. 81-83).

6 Cf., for example, the doxology of Heinrich Schütz's Psalm 100 (SWV 36), of which I propose the following personal interpretation. It begins with an evocation of the three Persons: the two choirs, four-part each, are scored at first for one part each (in echo) when the Father is mentioned. A second voice enters when the Son is evoked, building a counterpoint by contrary motion with the upper voice, giving the idea that the Son is the Father's "image" ("mirror"). In the third period, dedicated to the Spirit, a third voice is inserted, with a triad repeated thrice and followed by a vocalise suggesting the Spirit's "hovering" over the waters. It is therefore meaningful that Schütz suggests here a path that can be summarised as monody, polyphony and harmony: all of these are symbols of Trinitarian love. Similarly to Bach, on the other hand, Messiaen modifies the mirror-like quotation in his Méditations sur le Mystère de la Sainte Trinité. Although the verbal texts preceding the Méditations V and VII suggest that the Son's theme is an inversion of the Father's ("comme deux regards qui se croisent"), nevertheless, as Bruhn points out, the differences between the original and its supposed inversion suggest the differences between the two Persons. These were pointed out, among the others, by St. Thomas - one of Messiaen's favourite authors - and therefore their musical "signifiers" cannot be merely the mirror of each other (cf. [47], p. 110). 
Seraphim, ${ }^{7}$ composed respectively $(1567-1643)$ by Claudio Monteverdi and Francisco Guerrero (1528-1599). In Monteverdi, the words "et hi tres" are set into music on the same triadic chord, in three parts, whereas in the immediately following words ("unum sunt"), the three parts join together in unison on the G (cf. [48]) (see Figure 1 below).

Figure 1. Claudio Monteverdi, Vespro della Beata Vergine, 1610, "Duo Seraphim.”

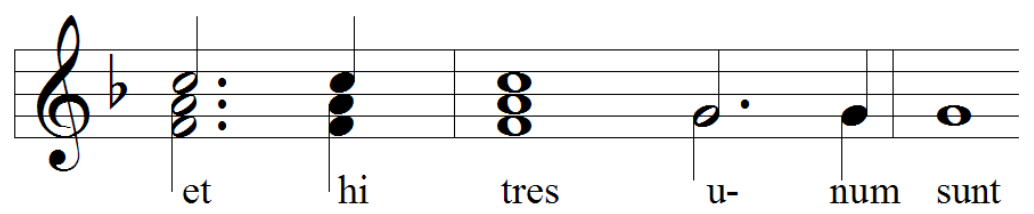

Guerrero's Duo Seraphim is in turn one of the most surprising and revealing symbolic representations of the Trinity in music. The words "tres sunt" are set onto an octave and a fifth, which were commonly used by many composers in a symbolic fashion; the three divine Persons' names are proposed in a highly suggestive musical illustration. "Pater", "et Verbum", "et Spiritus Sanctus" are sung by the different choirs: the first choir prolongs its concluding triad, which thus remains while the second choir sings "et Verbum" starting on the same chord. Therefore, it is as if the triad representing the Father (although, being a triad, it already alludes to the whole Trinity...) generated the second choir: their distinction is clear (the first choir keeps sustaining its own chord, which is therefore heard as freely existing), as is their perfect concord.

Another extremely effective solution is the one immediately following, on the words "et hi tres unum sunt". Here the different choirs alternate and take turns in singing the same triad. The same sound (the same chord) is heard as if coming from different points of the space, as if brought into life by the preceding choir: the result is similar to a phenomenon of enhanced echo (a sound coming from a point, which is reflected and "regenerated" by its contact with an obstacle).

Although space limits prevent a deep treatment of this subject, the symbolic use of polyphony in instrumental works in a Trinitarian sense is worth mentioning. In detail: the possibility of performing several melodic lines at a time, and its common liturgical use, made the organ a particularly fitting symbol for such representations. From the iconographic viewpoint, this symbology was used by, among others, Athanasius Kircher and Jan van Eyck. As concerns Kirchner, Figure XXIII of his Musurgia Universalis (1650) represents a gigantic organ. It is composed of three (and three) large groups of pipes, each counting seven elements, whereas the visible registers are three and three at both sides of the keyboard. The most curious element, however, is the keyboard itself. As perhaps even the non-musicians may know, piano and organ keyboards' octaves include seven white keys and five black ones, which are divided into two groups of two and three keys respectively. Kircher's organ, instead, has only groups of three black keys, forming (with the white ones), a series of "octaves" of seven semitones $(4+3)$ instead of the "normal", "human" twelve $(4 \times 3)$ semitones. As Kerala Snyder suggests, the concept underlying the idea of making this instrument practically unusable could be the idea of "consecrating [putting aside] this organ for God", especially since the text below says: "Sic ludit in orbe terrarum aeterna Dei sapientia". Similarly, the scroll over the organ titles the image as

This is one of the Trinitarian texts par excellence among those set to music in Western culture. This is inspired by Isaiah's vision (Is 6:1-4). Monteverdi’s version is part of his Vespro della Beata Vergine Maria (1610). 
"Harmonia nascentis mundi". Actually, the organ is surmounted by six circles, representing the six days of divine creation. Air, in small clouds, comes out from the organ pipes: possibly to symbolise the effusion of the Spirit. The instrument is playing at full volume: probably referring to humankind as creation's accomplishment ([49], vol. 2, p. 367; cf. [50], pp. 1-2).

As regards Jan van Eyck, it has been observed that the keys pressed down by the angel who plays the organ in the polyptych on the adoration of the Mystic Lamb are C/G and E. Incidentally, this open harmony corresponds very strictly both to the series of the harmonic sounds and to the concept of the triad as a Trinitarian metaphor, with the Father being symbolized by the root, the Son by the fifth and the Spirit by the third. Moreover, according to Brand Philip, the central image of the polyptych's upper section represents the Trinity: the painter's reference thus becomes particularly poignant (cf. [51], p. 54). Centuries later, Albert Schweitzer saw in the physical structure of organ itself (i.e., in the Hauptwerk, Rückpositiv and Schwellwerk) a Trinitarian icon ([52], p. 69).

It is however not an exclusive prerogative of the organ: an instrumental three-part polyphonic writing symbolising the Trinity is found, for example, in several piano work by Charles Tournemire (in the Douze Prélude-Poèmes for the piano, especially nos. 9-12) and Olivier Messiaen. ${ }^{8}$

\section{A "Harmonious" God}

Already during the Ars-Nova period, the interval of third starts to appear among the allowed consonances, probably in consequence of the influence of British music: at first as passage note (i.e., as a non-consonant, or not totally consonant interval, which could be tolerated between two consonant notes), and later as an "imperfect" consonance ([36], p. 321). It was not before the $16^{\text {th }}$ century, however, that the concept of "triad chord" was established". It is perhaps interesting to consider here the German theorist Johannes Lippius (1585-1612), who perfectly summarized the concept of his time, as the result of the progressive intensifying of an awareness coming from the preceding centuries. ${ }^{10}$ For Lippius, the triad ("trias harmonica perfecta") is "imago et umbra magni mysterii divinæ solum adorandæ Unitrinitatis" ([55]; cf. [56], pp. 40-49). This same concept has been developed in recent times by Paolo Venturino in a series of deep, fruitful and thought-provoking observations on the Trinitarian symbolism of the triad ([57], pp. 67ff; cf. [58]). ${ }^{11}$

8 For example, in the Vingt Regards sur l'Enfant-Jésus, (e.g., no. 1, Regard du Père; in the Regard du Fils sur le Fils etc.); among the organ works, cf. the last movement of Les Corps Glorieux (1939), "Le Mystère de la Sainte Trinité", and, obviously, the Méditations sur le Mystère de la Sainte Trinité. Cf. [53].

9 Up until then, actually, the three notes forming the triad were not conceived as a self-standing "harmonic" entity proper, but rather as the juxtaposition of two consonant harmonic intervals (cf. [54], p. 188).

${ }^{10}$ He was the first to formalise the concept of chord inversion, according to which the chords "C-E-G", "E-G-C" and "GC-E" are three versions of the same triad.

11 The argument maintained by Venturino is part of a wider discussion, aiming at demonstrating the presence and the theological value of a particular temperament of keyboard instrument created by Johann Sebastian Bach. According to Venturino, the composer ciphered his tuning system in the autograph title-page of the Well-Tempered Keyboard I (1722). We are omitting here, in a simplistic way, the complex acoustic/mathematical implications of Venturino's argument; however, it is interesting to quote here some of his statements concerning the Trinitarian values of the triad. 
The triad $^{12}$ is the fundamental element of classical Western harmony, as it is the chord that summarizes and defines the whole key. This chord is based on the first six harmonics, forming intervals of fifth and (major) third with the tonic. According to many Renaissance theorists, the number six represented the days of creation; the three notes of the chord referred to the Creator. It was therefore an icon of the "heavenly harmony sounding in perpetuity in the ear of God" ([61], p. 124).

It may be pertinent to consider here the educational and catechetic value of the observations on the Trinitarian analogies of the tonal system, as pointed out by John Butt. For him, "practical" music had the function of transmitting moral and religious values and principles; to this end, the possibilities offered by the speculation on the Trinitarian image of tonality were particularly fruitful. According to Butt, theologians who had musical knowledge immediately linked the emergence of the "new" tonal system with the concept of Trinity. He continues by highlighting that the natural phenomenon of the harmonic sounds could appear to be almost "scientific evidence" of Luther's theory, according to which music is a gift of God. During the dedication of an organ, in 1631, the sermon of G. Friccius stated this point in a very clear and evident fashion ([62], p. 35, quoted in [63], p. 39).

From the acoustic and psychoacoustic viewpoint, the feeling of stasis, calm, solidity and safety aroused by the perfect chord make it particularly suitable for symbolizing acoustically the divine reality, which is immutable, eternal and solemn. Beethoven himself chose to use the triad for the words "Deum de Deo", "Deo vero" and "Et vitam venturi saeculi" within the Credo of his Missa solemnis (cf. [64], p. 684).

It is worth mentioning that Andreas Werckmeister, who developed a famous temperament bearing his name to the present day, had an allegoric and symbolic concept of tuning. The speculative appendix "Von der Allegorischen und Moralischen Musik" in his treatise Musicae Mathematicae maintains that God, who is ineffable (unbegreifflich) and hidden (verborgen) is revealed not only through Scripture but also through nature and art. For Werckmeister, therefore, the scale's notes represent allegories of the creation as well as of the days of God's creative activity; moreover, their functions symbolize the Trinity ([65], p. 141; cf. [4], p. 417).

The connection between the order of creation, the order of numbers and that of musical composition, which is to be found throughout Western thought for centuries, was developed in the Baroque era by important theorists, among whom was Kepler: together with Mersennes and Kircher, he wrote one of the most important Baroque treatises on this subject [66,67].

These were the years of music's establishment as an autonomous source of transcendent and cosmic symbolic meanings. In the early Baroque era, music took its symbolism mostly from its connection with verbal language: music "illustrated", also through numerology, the words' meaning and significance. Later, it was the form of music itself, with its internal order, which made it part of the cosmic harmony, and, therefore, a mirror of divine wisdom ([68], col. 1974-76).

Concepts similar to this are found throughout the history of philosophy, theology and music theory. For Kircher, God could be defined as the "great Harmostés" ([49], vol. 2, p. 462). The Greek term's semantic value is much greater than "governor" or "ruler", by which it is commonly translated. Indeed, it contains a reference to "harmony, to him who rules in the reciprocal consent of the parts involved" ([69], p. 28, fn. 44). In his treatise, Kircher perfectly represents the concept of his

12 On this subject, cf. also [58-60]. 
contemporaries, of a "world ordained according to number and mathematics in a theological perspective. The harmony of spheres, that of musical sounds and that among body, senses and souls - although referring to different fields of knowledge - all refer to the perfection of the Creator's work" ([69], p. 28; cf. [4], pp. 374-75).

Kircher's thought will prove influential in the Baroque era, although sometimes they will be used as an ex-post justification for the increasingly important (and independent) role of music, even within liturgy, rather than as a genuine reflection on the theology of music ([4], p. 384; cf. [70], pp. 17-18). Nonetheless, even keeping a due "distance" and establishing precise and well-defined layers of thought and reflection, the harmonic metaphor has such potentialities and has been so constantly exploited in the last four centuries that it is necessary to consider it attentively (cf. [2], pp. 152ff.; [60], especially $\S \S 29-50)$.

The triad consists of three notes, all equally indispensable, and is also the space where both the height and the hierarchy of all the other notes of the scale are defined. The three notes of the triad built on the tonic have different functions, but are all in relation to each other, as well as with the entire tonal space. The root is the generating element of both the chord and the key: although it is a specific, particular and individual note, it has already in itself a relationship, a musical fecundity, which is represented by the series of harmonic sounds. The tonic does not contain the scale only potentially, but in act. At the same time, the tonic cannot be conceived only as a simple mathematical set, of which the other notes are merely the elements: the tonic "gives life" to a world of sounds living in it.

The tonic represents, furthermore, the resting point and the centre of gravity in the key; it is the note towards which all tonal movements are oriented. At the same time, the tonic plays this role of tonal basis both as a single note (e.g., the C) and as the perfect chord, i.e., in interaction with the remaining notes of the triad: they are implicit in the tonic's function even when they are not actually heard. ${ }^{13}$

The chord's fifth has a different function. According to Venturino, it could represent the Son: in its traditional name of "dominant", it depicts man, "who stands up, walks straight, is raised onto the cross of life, but also in the Transfiguration and Ascension" ([57], p. 67). It may also allude to Christ's five wounds or the human being tout court, with their five extremities (two arms, two legs and the head). The "dominant" is in turn the origin of the other great chord, which is named after it and represents tension in its constituent relationship with the tonic. Although it has a sense of its own, it inexorably tends towards the triad. The note generating it thus becomes a "mediator" between the tonic's world of stillness and the dynamism of the remaining notes of the scale. The fifth grade can generate, moreover, the chords of dominant seventh and ninth: in the latter case, the root of the chord (i.e., the fifth grade of the scale, which is part of the triad as well) "generates" a chord made of all the notes not included in the triad. Therefore, it relates the whole tonal "world" of the tonic with the tonic itself.

The third grade of the scale (mediant), finally, is what makes the triad a true chord. Its presence immediately qualifies the major or minor key. It is, so to say, the note, which gives warmth and life to the triad. A void fifth would be doubtlessly consonant, but still, static and without communication with the external world; the third gives it a personality and a color.

13 In other words, if a single $\mathrm{C}$ can conclude as a tonic a work in $\mathrm{C}$-major, its being in a relationship with the $\mathrm{E}$ and the $\mathrm{G}$ will be implicit even if the $\mathrm{E}$ and $\mathrm{G}$ are omitted. They are present both in the listeners' memory and also, actually, among the harmonics of the $\mathrm{C}$. 
The interaction among the notes of the triad would refer, in turn, to the intra-Trinitarian relationships: "The dominant and the third are in turn harmonics of the tonic. Thus they derive from the Father, but the Father would not be revealed without them, being a sterile tonic, a motor immobilis, as Aristotle said. Dominant and third reveal the Father: the former with the vital and sacrificial raising, but also with the following realization of glory; [...] the latter with the fulfillment of taste (Love, the Spirit) [...] which leads from the tonic to the dominant/Son" ([57], p. 54). A clarification is now necessary. A discourse on musical harmony is rich, complex and fascinating; one on the Trinity is, for obvious reasons, infinitely richer, more complex and fascinating; and it is possible to attempt suggestive comparisons between these two worlds; nevertheless, in my opinion, the experiential aspect (so crucial for both) can reveal, much more than any speculation, the "truth" of a relationship.

In other words, musical harmony is certainly a "symbol" for certain aspects of Trinitarian life; but it is also an actual creature of the Trinity, a created reality donated by God to humankind. The parallelism thus is not simply a figurative analogy, but becomes, here too, a relationship. Similarly, it is much more fruitful, in my opinion, to "perceive" how musical harmony can be a shadow of the Trinity's harmony, instead of reducing this "proximity of beauty" to a merely mechanic equivalence. Obviously, if the minutiae of a theological discourse on the Trinity have often enflamed the doctrinal debate, with the progressive definition of the dogma and the establishment of an appropriate linguistic framework, the same cannot be said of the musical language, whose precision and conceptual meaningfulness are totally different: it is only within a framework of faith and worship that the "Trinitarian" meaning or implication of music can be lived, experienced and transmitted (cf. however [2], pp. 154-55).

We can, therefore, realize that many of the tonic's functions can be assimilated to some of the Father's attributes, in primis as concerns the generative function of the tonic in both the triad and the whole tonal space. It would be much more problematic to apply a hierarchic structure to the Trinitarian relationships in consequence of the observations on the harmonic sounds, as it is obviously impossible to reduce the Trinity to an acoustic phenomenon. It is similarly fascinating to see a symbol of the Son's double nature in the pivotal function of the dominant. Within the triad, we can say that tonic and dominant "look at each other", are in direct relationship, which is both dialectic and concordant. It is therefore rather easy to see, in this polarity, a symbol of the Son as the Father's image, and as the One who constantly "looks at" him. Thus, the fifth grade, giving life (within the space determined by the tonic) to the dominant chord, is part both of the "still" and self-sufficient world of the triad, and of the world gravitating around it: a world which, to use Augustine's famous sentence, "is restless until it rests" in God. It is similarly "easy" to recognise in the quality brought by the third to the triad a symbol of the Spirit's action, which gives color and life to the relationship between tonic and dominant, thus preventing the simple interval of fifth from remaining a closed and non communicative reality.

These are all possible images, and, probably, they have a certain validity besides their merely suggestive value. However, as a musician I must say that the concept of musical harmony as a symbol of divine harmony, when actually heard, is much more beautiful and richer than what is simply deducible from the similarities above. There is a genuinely experiential "communicativeness" that strikes us as a revelation of beauty when we "perceive" that "there is something of God", a trace of a divine and Trinitarian reality, in the stupendous richness of a fruitful, warm and vibrating harmonic movement that we may experience while listening to three singers with perfect intonation. I apologize to my readers for the very personal quality of such impressions, but I think it important to attempt to 
communicate them; and this is impossible without a direct experience. Indeed, one feels an intellectual, symbolic, rational fascination in the possibility of a timid reasoning on the Trinity through the aural reality of harmony; however, there is a much higher, stronger and realer fascination in the transcendence of this same discourse, above all theoretical and mental associations, and within a reality of beauty speaking to the heart, much more than to rational speculation.

Moreover, if different vocal parts (e.g., three voices singing a triad) have a truly good intonation, and are sung by people acquainted with listening to another's voice, and to uniforming their timbre to each other's, the aural result will be the closest human symbol for a perfect communion. The resulting sound will have an immediately communicable character of unity, of harmony, and, as it were, of individuality as well; at the same time, it is possible to discern and distinguish the simultaneous presence of different human voices. It is precisely their being in a reciprocal "relationship" (i.e., to tune oneself to the other's voice) that creates their consonance, the overall musical reality, which cannot be reduced to the sum of each individual's contribution.

From an acoustic viewpoint, moreover, if different voices are singing a triad with a perfect intonation, the harmonics shared by the different voices will be very numerous. Thus, they will be intensified and strengthened, becoming clearly perceptible to an attentive listener: the merging of sounds thus produces a stunning effect, in which the revelation of the harmonic sounds is almost an acoustic "gift", something resulting from the perfection of intonation, characterizing the chord itself unmistakably, unequivocally and inimitably. In other words, a simple chord C-E-G, sung by three voices in perfect intonation, is an acoustically "living" reality, a "generative" reality, which produces and arouses its own sounds. All singers produce their own harmonics together with their own root; but the harmonics resulting from the melting of their voices will not simply be the sum of those produced by each individual voice, as their interaction produces very peculiar sonorities, which cannot be ascribed to any of the individual singers.

It is noteworthy, here, to point out the strong symbolic value of the "human" component of the voices' harmony. This reality, which is irreducible to the sum of its components, this sound which generates other sounds, can result only and exclusively from a "community" listening to itself. The generation of that wealth of harmonics is impossible unless all singers listen with the utmost attention to what their neighbor is singing. As a musician, I remember being very impressed by an interview with of one of the King's Singers, who said: "The way of singing we learnt when children remained within us until now, and it is a very British sound. Emphasis is not put on vocal technique in order to produce [...] the vibration of the whole body. On the contrary, our aim is to blend perfectly and delicately our voice with that of the others, exactly as we did when children" [71]. In Christian terms, this is a perfect metaphor of the communion realized through the reception of the other, the openness and the hearing, and through charity, the intra-Trinitarian bound par excellence. The intra-Trinitarian dynamics are compared to a chord of voices by Jenson as well: he uses the musical metaphor as a very concrete symbol rather than as a simple poetic imagery. The reciprocal exchange between the three divine Persons is a "singing" exchange, in Jenson's words; the eternal dialogue between Father, Son and Spirit becomes beauty since it is total harmony and has no other goal besides itself [72]. Thus, to quote Edwards, Heaven, the "society in the highest degree happy" is made of souls who express "their love, their joy, and the inward concord and harmony and spiritual beauty [...] by sweetly singing to each other" ([73], p. 619). The beauty of a redeemed Creation is therefore in the reciprocal concord 
"between one mind and another, and between all their minds and Christ Jesus [...], and among the persons of the Trinity, the supreme harmony of all!" ([74], p. 329, no. 182).

\section{Conflicts of Interest}

The author declares no conflict of interest.

\section{References and Notes}

1. Samuel, Claude. Permanences d'Olivier Messiaen: Dialogues et Commentaires. Paris: Actes Sud, 1999, 21. An Italian translation of this article has been published on the online theological journal "Reportata" (http://mondodomani.org/reportata).

2. Fitzpatrick, Kathleen. "Trinity and Music: Intonations of the Triune God." In Trinity and Salvation. Theological, Spiritual and Aesthetic Perspectives. Edited by Declan Marmion and Gesa Thiessen. Bern: Peter Lang, 2009, 141-60.

3. Clement of Alexandria. Exhortation to the Heathen (Protrepticus). Available online: http://books.google.it/books?id=tYHjz6J3OrYC/ (accessed on 6 October 2013).

4. Rainoldi, Felice. Traditio canendi. Appunti per una storia dei riti cristiani cantata. Rome: CLVEdizioni Liturgiche, 2000.

5. Stoltzfus, Philip. Theology as Performance. Music, Aesthetics and God in Western Thought. Edinburgh: T \& T Clark, 2006.

6. Herrero de Jáuregui, Miguel. "The Protrepticus of Clement of Alexandria: A Commentary." Doctoral Thesis, University of Bologna, 6 February 2008. Available online: http://amsdottorato.cib.unibo.it/1117/ (accessed on 6 October 2013).

7. Galloni, Matteo. Cultura, Evangelizzazione e Fede nel Prottrettico di Clemente Alessandrino. Rome: Studium, 1986.

8. Migne, Jacques Paul. Patrologiae Cursus Completus, Series Graeca. Paris: Garnier Frères, 1856-1866, 161 volumes. Available online: http://graeca.patristica.net/ (accessed on 6 October 2013).

9. Augustine. The Trinity. Edited and translated by Edmund Hill, OP. New York: New City Press, 1991.

10. Tscholl, Joseph. Dio \& il Bello in Sant'Agostino. Milan: Edizioni Ares, 1996.

11. Broadie, Alexander. The Shadow of Scotus. Philosophy and Faith in Pre-Reformation Scotland. Edinburgh: T. \& T. Clark, 1995.

12. Gunton, Colin. The Triune God. Edinburgh: Edinburgh University Press, 1988.

13. Ratzinger, Joseph. "Musica e liturgia." Communio 171, May-June 2000, 37-48.

14. Hart, David Bentley. The Beauty of the Infinite: The aesthetics of Christian Truth. Grand Rapids: Eerdmans Publishing, 2003.

15. Dreyfus, Laurence. Bach and the Patterns of Invention. Cambridge, MA: Harvard University Press, 2004.

16. Wolff, Christoph. Johann Sebastian Bach: The Learned Musician. New York: Norton, 2000.

17. Begbie, Jeremy S. Resounding Truth. Christian Wisdom in the World of Music. Grand Rapids: Baker Academic, 2007. 
18. Horne, Brian. “Art: A Trinitarian Imperative?" In Trinitarian Theology Today. Edited by Christoph Schwöbel. Edinburgh: T. \& T. Clark, 1995, 8-91.

19. Jenson, Robert W. Systematic Theology. The Triune God. Oxford: Oxford University Press, 1997.

20. Von Bingen, H. "Lettera 23." In Hildegardis Bingensis Epistolarium. Pars Prima I-XC (Corpus Christianorum Continuatio Mediaevalis). Edited by Lieven van Acker. Turnhout: Brepols, 1991, vol. 91, 61-66.

21. Augustine. The Retractations. Translated by Sister Mary Inez Bogan, RSM. Washington: The Catholic University of America Press, 1968 (1999).

22. Augustine. "The True Religion." In Augustine: Earlier Writings. Edited and translated by John Burleigh. Philadelphia: The Westminster Press, 1953.

23. Augustine. On Christian Teaching (On Christian Doctrine). Translated by James Johnston Shaw. Digireads.com, 2009, ebook.

24. Joseph Cardinal Ratzinger. "Music and Liturgy. How does the music express the Word of God, the Vision of God?" Adoremus Bulletin VII, no. 8, November 2001. http://www.adoremus.org/ 1101musicliturgy.html.

25. Von Balthasar, Hans Urs. Lo Sviluppo Dell'Idea Musicale. Milan: Glossa, 1995.

26. Migne, Jacques Paul. Patrologiae Cursus Completus. Series Latina. Paris: Garnier Frères, 1844-1855, 221 volumes. Available online: http://latina.patristica.net/ (accessed on 6 October 2013).

27. Wiora, Walter. "Das vermeintliche Zeugnis des Johannes Eriugena für die Anfänge der abendländischen Mehrstimmigkeit." Acta Musicologica 43, no. 1/2, January/June 1971, 33-43.

28. Hildegard von Bingen. The Book of the Rewards of Life. Translated by Bruce Hozeski. New York: Garland Publishing, 1994; Oxford: Oxford University Press, 1997.

29. Flynn, William T. “The Soul is Symphonic': Meditation on Luke 15:25 and Hildegard von Bingen's Letter 23." In Music and Theology: Essays in Honor of Robin A. Leaver. Edited by Zager, Daniel. Plymouth: Scarecrow Press, 2007, 1-8.

30. Pirro, André. Histoire de la Musique de la fin du XIVe Siècle à la fin du XVIe. Paris: H. Laurens, 1940.

31. Lord, Suzanne. Music in the Middle Ages: A Reference Guide. Westport: Greenwood Press, 2008.

32. Hughes, Dom Anselm. "Music in Fixed Rhythm." In Early Medieval Music. Up to 1300 (Vol. II of the New Oxford History of Music). Edited by Dom Anselm Hughes. London, New York, Toronto: Oxford University Press, 1954, 311-52.

33. De Coussemaker, Edmond. Scriptorum de Musica Medii Aevi Nova Series. Paris: Durand, 1864-1876, vol. 4.

34. Apel, Willi. The Notation of Polyphonic Music. 900-1600. Cambridge, MA: The Mediaeval Academy of America, 1949.

35. Vetulus de Anagnia, Johannes. Liber de Musica (vol. 27 of the Corpus Scriptorum de Musica). Edited by Frederick Hammond. Neuhausen-Stuttgart: Hänssler-Verlag, 1977.

36. Reese, Gustave. Music in the Middle Ages. With an Introduction on the Music of Alancient Times. New York: Norton, 1940. Italian translation by Flora Levi d'Ancona. La musica nel medioevo. Milan: Rusconi, 1990. 
37. Busse Berger, Anne Marie. "The Evolution of Rhythmic Notation." In The Cambridge History of Western Music Theory. Edited by Thomas Christensen. Cambridge: Cambridge University Press, 2002, 628-56.

38. Blankenburg, Walter. "Zahlensymbolik. A." In Die Musik in Geschichte und Gegenwart. Kassel: Bärenreiter, 1976, vol. 16.

39. Michels, Hans Ulrich, ed. Johannes de Muris: Notitia Artis Musica, et Compendium Musicae; Petrus de Sanct Dionysio: Tractatus de Musica. Rome: American Institute of Musicology, 1972.

40. Leaver, Robin A. Luther's Liturgical Music: Principles and Implications. Grand Rapids: Eerdmans Publishing, 2007.

41. Cunningham, David S. These Three Are One: The Practice of Trinitarian Theology. Challenges in Contemporary Theology. Oxford: Blackwell, 1998.

42. Bonhoeffer, Dietrich. Widerstand und Ergebung: Briefe und Aufzeichnungen aus der Haß. Munich: Christian Kaiser Verlag, 1970.

43. Von Balthasar, Hans Ulrich. Die Wahrheit ist Symphonisch. Aspekte des Christlichen Pluralismus. Einsiedeln: Johannes Verlag, 1972.

44. Milbank, John. "Postmodern critical augustinianism: A short summa in forty-two responses to unasked questions." Modern Theology 7, no. 3 (1991): 225-37.

45. Smith, Timothy A. "Anatomy of a Canon." Available online: http://www.kunstderfuge.com/ theory/smith/canon.htm (accessed on 6 October 2013).

46. Petzoldt, Martin. "Das Thema des Geistes und der Trinität bei Bach.” Musik und Kirche 69/2, March-April 1999, 80-89.

47. Bruhn, Sieglind. Messiaen's Interpretations of Holiness and Trinity. Echoes of Medieval Theology in the Oratorio, Organ Meditations and Opera. Hillsdale: Pendragon Press, 2008.

48. Whenham, John. Monteverdi. Vespers (1610). Cambridge: Cambridge Music Handbooks, 1997.

49. Kircher, Athanasius. Musurgia Universalis sive Ars Magna Consoni et Dissoni. Rome: Heirs of F. Corbelletti, 1650; anastatic reprint: Hildesheim: Georg Olms Verlag, 1970.

50. Snyder, Kerala J. "Praeludium. Organs as Historical and Aesthetic Mirrors." In The Organ as a Mirror of Its Time: North European Reflections, 1610-2000. Edited by Snyder, Kerala. New York: Oxford University Press, 2002, 1-22.

51. Brand Philip, Lotte. The Ghent Altarpiece and the Art of Jan van Eyck. Princeton: Princeton University Press, 1971.

52. Schweitzer, Albert. Aus Meinem Leben und Denken. Stuttgart: Stuttgarter Hausbücherei, not dated; Frankfurt: Fischer, 1959.

53. Michaely, Aloyse. "Messiaens Trinitätstraktate." Musik und Kirche 69/2, March-April 1999, 90-98.

54. Elders, Willem. Symbolic Scores: Studies in the Music of Renaissance. Leyden: E. J. Brill, 1994.

55. Lippius, Johann. Synopsis musicae novae omnino verae atque Methodicae Universae. Strasbourg: Carl Kieffer, 1612; translated by Benito V. Rivera as Synopsis of New Music. Colorado Springs: Colorado College Music Press, 1977.

56. Dammann, Rolf. Der Musikbegriff im Deutschen Barock. Cologne: Volk, 1967, 40-49. 
57. Venturino, Paolo. “L'universo secondo Bach.” In Bach 1722. Il Temperamento di Dio. Edited by Graziano Interbartolo, Paolo Venturino and Giampiero Bof. Finale Ligure: Edizioni Bolla, 2007, 43-108.

58. Hahn, Harry. Symbol und Glaube im I. Teil des Wohltemperierten Klavier von Joh. Seb. Bach. Wiesbaden: Breitkopf und Härtel, 1973.

59. Dahlhaus, Carl. "Der Dreiklang als Symbol.” Musik und Kirche 25 (1955): 251-52.

60. Schadel, Erwin. Musik als Trinitätssymbol. Einführung in die Harmonikale Metaphysik. Frankfurt: Peter Lang, 1995.

61. Ledbetter, David. Bach's Well-Tempered Clavier. The 48 Preludes and Fugues. New Haven: Yale University Press, 2002.

62. Friccius, Christophorus (aka Frick, Christoph). Music-Büchlein oder Nützlicher Berichte von dem Uhrsprunge, Gebrauche und Erhaltung Christlicher Music. Lüneburg: J. und H. Sternen, 1631; Kassel: Bärenreiter, 1976.

63. Butt, John. Music Education and the Art of Performance in the German Baroque. Cambridge: Cambridge University Press, 1994.

64. Kirkendale, Warren. "New roads to old ideas in Beethoven's Missa Solemnis." The Musical Quarterly 56, no. 4 (1970): 665-701.

65. Werckmeister, Andreas. "Anhang. Von der Allegorischen und Moralischen Music." Musicae Mathematicae Hodegus Curiosus Oder Richtriger Musicalischer Weg-Weiser. Frankfurt/Leipzig: Calvisius, 1687; reprinted Hildesheim: Olms, 1972.

66. Kepler, Johannes. Harmonices mundi. Libri V. 1619. Translated and edited as The Harmony of the World by Eric John Aiton, Alistair Matheson Duncan and Judith Veronica Field. Philadelphia: The American Philosophical Society, 1997.

67. Mersennes, Marin. Traité de l'Harmonie Universelle, où est contenu la Musique Theorique \& pratique des Anciens \& Modernes, avec les causes de ses effets. Paris: Guillaume Baudry, 1627.

68. Blankenburg, Walter. "Zahlensymbolik. A." Die Musik in Geschichte und Gegenwart. Kassel: Bärenreiter 1976, vol. 16.

69. Erle, Giorgio. Leibniz, Lully e la Teodicea. Venice: Il Poligrafo, 2005.

70. Luppi, Andrea, and Maurizio Padoan. Statuti Della Musica. Como: A.M.I.S., 1989.

71. Pantano, Marina. "Voci Senza Frontiere." Sistema Musica, 2002. Available online: www.sistemamusica.it/2002/gennaio/17.htm (accessed on 6 October 2013).

72. Jenson, Robert W. "Language and Time.” Response 8 (1966): 75-80.

73. Edwards, Jonathan. The Works of Jonathan Edwards. Edited by Henry Rogers. London: William Ball, 1839, vol. II.

74. Edwards, Jonathan. The Works of Jonathan Edwards. New Haven: Yale University Press, 1994, vol. 13.

(C) 2013 by the author; licensee MDPI, Basel, Switzerland. This article is an open access article distributed under the terms and conditions of the Creative Commons Attribution license (http://creativecommons.org/licenses/by/3.0/). 